\title{
A influência do poder econômico na aprovação de normas jurídicas e sua relação com as teorias sobre o pensamento jurídico contemporâneo
}

\author{
Vivian Leinz* \\ Daniel Francisco Nagao Menezes**
}

\section{INTRODUÇÃO}

\author{
"Todo o poder emana do povo, que o exerce por meio de \\ representantes eleitos ou diretamente nos termos desta Constituição"
}

Conforme determina esse dispositivo, o povo é o titular do poder, que o realiza diretamente ou por intermédio de representantes. A forma direta de manifestação do poder popular dá-se por meio do plebiscito, referendo e também iniciativa popular de lei; o voto é o modo indireto de exercício desse poder.

A manifestação direta do poder popular deve atender a uma série de requisitos. Com efeito, a iniciativa popular de lei, prevista na Constituição Federal (art. 61, $\$ 2^{\circ}$ ), depende de subscrição de no mínimo um por cento do eleitorado nacional, distribuído em pelo menos cinco Estados, com não menos de três décimos por cento dos eleitores de cada um deles. Quanto ao plebiscito e referendo, demandam autorização do Congresso Nacional (CF, art. 49, inciso XV), salvo alguns casos (CF, art. $18, \$ \$ 3^{\circ}$ e $4^{\circ}$ e art. $2^{\circ}$ do ADCT), sendo convocados por meio de decreto legislativo firmado por no mínimo $1 / 3$ dos membros de uma das Casas do Congresso Nacional (Lei 9.709/98, art. $3^{\circ}$ ). Portanto, foi rejeitada

\footnotetext{
* Essa constatação já leva a crer que o juspositivismo não é a única forma de pensamento contemporâneo atualmente existente no Brasil. O não juspositivismo - o direito é o que o detentor de poder diz, e não o que está nas estritas normas jurídicas - tem larga presença em nosso ordenamento jurídico, mesmo que não se admita formalmente.

** As informações criminas referente aos benefícios dessas duas empresas podem ser detalhadas na ação penal 0037544-46.2017.4.01.3400, em trâmite perante Juízo da $10^{\text {a }}$ Vara Federal Criminal do Distrito Federal.
} 
a convocação de plebiscito ou referendo por iniciativa popular. (MENDES, COELHO, BRANCO, 2007)

Desse cenário extrai-se que a manifestação direta do poder popular, apesar de prevista na Constituição, é praticamente inexistente. Plebiscito e referendo não são verdadeira expressão da vontade do povo, porque dependem de convocação do Legislativo. Já a iniciativa popular requer o preenchimento de tantas condições que praticamente é inviabilizada.

Desde a promulgação da Constituição Federal de 1988 somente foram aprovados quatro projetos de iniciativa popular, sendo que todos eles acabaram sendo "adotados" por parlamentares simpatizantes das causas apresentadas, não tendo seguido propriamente o procedimento de iniciativa popular sob a alegação da Câmara de não possuir "estrutura" para a conferência dos votos.

Assim, resta ao povo o exercício do poder, que lhe foi constitucionalmente atribuído, por meio de representantes eleitos. Essa representatividade, no entanto, está longe de ser adequada. Sobram notícias de parlamentares corruptos, de defesa de interesses pessoais, descumprimento dos programas a que se comprometeram, cooptação por terceiros e até mesmo de total inércia, com a ausência reiterada do local de trabalho.

Nesse contexto, Bagnoli (2009, p. 82-83) assevera que a democracia representativa não garante a soberania popular, tendo sido criada para assegurar os interesses do poder econômico: "A democracia moderna é formal, fundada na representação popular, que acaba por limitar a soberania do povo. Toda essa invenção foi estruturada para consolidar a relação público-privado e assegurar os interesses soberanos do poder econômico".

Nesse ponto que queremos chegar: a influência do poder econômico na soberania do povo e as consequências advindas da intrincada relação públicoprivado. E mais, essa ingerência não seria também uma demonstração de que na prática não temos o "império da lei", de que na verdade o juspositivismo é somente uma figura retórica?

\section{A RELAÇÃO PÚBLICO X PRIVADO}

A linha entre o que é público e o que é privado é muito tênue. O Estado depende do poder econômico e a existência desse depende daquele. Os poderes público e privado se mesclam, se misturam, de tal forma que não é possível separálos. Há uma simbiose entre o poder público e o privado, separação e convergência.

Como relata Bagnoli (2009, p. 69), a relação entre poder público e poder privado baseia-se na troca de interesses. O poder público edita leis que beneficiam o poder privado, o qual, em contrapartida, paga tributos e apoia os conflitos armados, comerciais e econômicos encabeçados pelo Estado. Um não existe sem o outro. 
Tanto o poder público quanto o privado possuem vantagens nessa relação, formando um macrossistema de apoio recíproco. Nesse cenário teoricamente paira o equilíbrio. O Estado tem o apoio do poder econômico para implantar as suas políticas públicas e recebe tributos, ao passo que o poder econômico tem liberdade para atuar no livre mercado, tendo suas atividades resguardadas pelo ambiente de segurança e garantia assegurado pelo Estado, tudo em nome do bem comum e da paz social. Mas não é exatamente isso que ocorre na prática.

Conforme dito linhas acima, a democracia moderna é um engodo, na medida em que não prestigia a soberania popular. Ou melhor, sequer permite que referida soberania exista. As normas insertas na Constituição Federal para garantila são "letra morta", de modo que o povo não goza efetivamente do poder que lhe foi atribuído constitucionalmente. O governo não é do povo para o povo; o poder não emana do povo e não é por ele exercido. E tal condição leva a desequilíbrios na relação entre o poder público e o privado, gerando invariáveis abusos.

Uma das consequências mais nefastas dessa relação desvirtuada entre o poder público e o privado se dá no que tange ao exercício do poder legislativo para atender interesses exclusivamente particulares. A edição de normas jurídicas a favor de uma minoria em detrimento de uma maioria é mais frequente do que se imagina, e via de regra decorre da influência do poder econômico sobre o legislador, o qual termina por agir contrariamente ao interesse público, deixando de atender à consecução do bem comum e à defesa do interesse da coletividade.

Esse fenômeno demonstra a falência da soberania popular e, por tabela, da democracia. Volta-se de certa forma ao Estado absolutista, no qual se confundiam os interesses públicos e privados ao redor da figura de um soberano, com a diferença de que agora o monarca não é um, mas um conjunto de pessoas, os representantes dos Poderes Legislativo e Executivo e seus agregados. Prova disso é o desdém com o interesse público, a ausência da figura do Estado na sua concepção essencial e, derradeiramente, a prevalência da vontade de uma minoria representativa do poder econômico, minoria essa que às vezes se confunde, de maneira patológica, com os próprios "representantes" do povo, eleitos segundo o procedimento previsto em nossa Carta Maior.

Nas linhas a seguir demonstraremos, na prática, o acima exposto. Contudo, antes faremos uma breve incursão pelas teorias que integram o pensamento jurídico contemporâneo, as quais podem explicar o fenômeno acima delineado.

\section{O PENSAMENTO JURÍDICO CONTEMPORÂNEO}

O pensamento jurídico contemporâneo, segundo Mascaro (2015), possui três correntes de pensamento: juspositivismo, não juspositivismo e crítico. Todas essas vertentes trazem o Estado como figura central, sendo o direito forma de manifestação estatal, condição que o afasta de concepções religiosas e morais. 
Contudo, para cada uma desses caminhos, o Estado assume um papel diferente na construção do direito, afetando a forma pela qual ele se apresenta.

\subsection{Juspositivismo}

Tendo como seu representante mais notório o consagrado alemão Hans Kelsen, cuja principal obra é a Teoria Pura do Direito, o juspositivismo enxerga o direito estritamente balizado pelo Estado. A norma jurídica é concebida pelo Estado, dentro de seus limites estritos. Somente é norma jurídica aquilo que emana da autoridade estatal, respeitado o processo legislativo previsto na lei suprema, a Constituição Federal. $\mathrm{O}$ direito se resume à norma jurídica, entendida como tal a regra contida na lei em sentido amplo.

O juspositivismo, na lição de Mascaro (2015), pode ser dividido em três espécies: (i) juspositivismo eclético, (ii) juspositivismo estrito e (iii) juspositivismo ético.

O juspositivismo eclético defende que o direito se resume, formalmente, ao disposto nas normas estatais. Todavia, ele resulta de fontes externas ao próprio direito, como a cultura, a moral e outros valores sociais. Assim, o direito é formalmente estatal, mas materialmente ele extrapola esse âmbito, tendo procedência estranha ao Estado. Por isso que, para essa corrente, o direito positivo varia de acordo com cada povo, na medida em que diretamente influenciado por suas características intrínsecas.

O juspositivismo estrito, que representa a corrente básica juspositivista quando nos referimos a ela de forma genérica, tem como seu precursor Hans Kelsen. Para ele, o direito, sob o ponto de vista formal e material, se resume à norma, esta entendida como emanação do poder estatal. Não só sua forma, mas também seu conteúdo estão dentro do próprio ordenamento jurídico, criando ele sua famosa alegoria - a "pirâmide de Kelsen" - para demonstrar que o direito é somente aquilo que está nas normas jurídicas, havendo um escalonamento entre elas no qual todas devem respeito à norma jurídica suprema - a Constituição. Nada externo a essas normas é direito; o que não está nas normas jurídicas, assim entendidas como atos originários do poder estatal, não existe. O fenômeno social, sem a incidência das normas estatais, equivale ao nada.

Por fim, há o juspositivismo ético, que se preocupa com a ética no direito. Segundo essa corrente, que tem algumas ramificações, como aquela encabeçada por Jürgen Habermas, basicamente o direito deve ser permeado por princípios éticos. Esses, no entanto, ao contrário do que ocorre no juspositivismo eclético, estão dentro do próprio direito, não sendo anteriores ou externos a ele.

\subsection{Não juspositivismo}

Assim como as demais vertentes do pensamento jurídico contemporâneo, o não juspositivismo também tem gradações. No entanto, a linha mais destacada 
do não juspositivismo é a capitaneada por Carl Schmitt, alemão que flertava com o nazismo e opositor de Hans Kelsen.

Para Schmitt o direito não estava somente nas regras postas pelo Estado. O direito é ditado por quem tem o poder, que é justamente aquele que tem a autoridade para criar a norma, mas também revogá-la ou deixar de cumpri-la. $\mathrm{O}$ poder está acima das normas estatais.

Ao contrário da teoria de Kelsen, para Schmitt (MASCARO, 2015, p. 59) "o direito é situacional. O poder é maior que o seu momento normativo"; " [...] o poder é maior que o direito positivo. Daí que a verdade do direito tem de ser entendida com elementos maiores que o próprio juspositivismo".

Em suma, o direito está no poder, e não só nas normas positivas, estando em quadrantes maiores do que essas.

\subsection{Pensamento jurídico crítico}

Tendo como principais expoentes Evgeny Pachukanis e Karl Marx, essa corrente filosófica entende, assim como os não juspositivistas, que o direito vai além das normas estatais, estando intrinsecamente ligado ao poder. Todavia, vai mais longe, buscando entender os fundamentos desse poder; as circunstâncias sociais, econômicas e políticas que levam a ele.

Segundo Mascaro (2015, p. 61)

"Ao invés de situar apenas o direito nas normas do Estado, como fazem os juspositivistas, Marx, Pachukanis e a tradição marxista se põem a indagar a respeito do porquê dessa mesma forma jurídica estatal. Enquanto os demais não juspositivistas apontam o direito em quadrantes maiores que o da norma jurídica, no poder, o marxismo desvenda as especificidades assumidas por esse poder no próprio capitalismo".

Diferenciando juspositivismo, não juspositivismo e pensamento crítico, Mascaro (2015, p. 61) arremata:

"Identificar o direito ao Estado é próprio do juspositivismo. O não juspositivismo aponta um poder que passa pelo Estado e é maior que o próprio normativismo. O marxismo se dedica a compreender porque esse poder assume a forma específica política e jurídica estatal, encontrando seu fundamento último na própria necessidade lógica da reprodução capitalista."

Expostas as principais linhas do pensamento jurídico contemporâneo, demonstrar-se-á na prática a próxima e por vezes promíscua relação entre interesses público e privado. 


\section{A CAPTURA LEGISLATIVA}

O poder tem grande influência na criação da norma. Somente o detentor de poder pode editar regras jurídicas e, na maioria das vezes, o faz em favor desse próprio poder (legislação em causa própria), ou de outros que lhe deem suporte e que, portanto, tem influência sobre ele, como o poder econômico ${ }^{1}$.

Como exemplo de norma editada com o único viés de favorecer o próprio poder de quem a edita tem-se a aprovação de aumentos dos subsídios dos parlamentares por eles mesmos, a criação de foros privilegiados, a descriminalização de determinadas condutas antes a eles atribuídas como delito. Já como exponente de normas originadas com o intuito exclusivo de favorecer terceiros há os incentivos fiscais, a inserção de pequenos comandos em favor de certo grupo de pessoas, a alteração de regras de planos de saúde em detrimento dos consumidores, dentre outras infindáveis hipóteses.

Para que o legislador atue em prol de determinadas pessoas ou grupo de pessoas, impõe-se em regra uma postura ativa por parte desses interessados, os quais se utilizam de alguns mecanismos de influência para atingir seu escopo.

As duas formas mais comuns de cooptar o legislador para que ele atue em favor de interesses particulares quando da elaboração das normas, sejam elas regulamentares, legislativas ou constitucionais, são o lobby e a captura (FERRAZ JUNIOR, SALOMÃO FILHO, NUSDEO, 2009). Além dessas, não podemos deixar de mencionar a corrupção.

O lobby é a influência exercida por determinado grupo de pressão ou de interesse e que, ao contrário do que se pensa, para ser efetivo deve ser formado por somente um pequeno conjunto de pessoas, com um interesse exclusivo.

A fim de evitar os conhecidos abusos oriundos da prática de tal atividade, há projeto de lei em tramitação no Congresso Nacional (PL 1202/2007, proposto por Carlos Zarattini, mas que foi modificado pela deputada Cristiane Brasil), que regulamenta a atividade de lobby e dos grupos que a exercem perante os órgãos e entidades da Administração Pública Federal.

A iniciativa de se regulamentar a atuação desses grupos de interesse é louvável, uma vez que há vários problemas envolvidos nessa atividade. A começar pelo fato de que nem todos têm as mesmas condições e oportunidades de realizar essa pressão: o lobbying normalmente fica restrito a grupos empresariais e organizações detentoras de poder econômico, o que já fere o equilíbrio democrático.

Interessante notar que o próprio projeto de lei que visa a regulamentar o lobby sofreu pressão de um determinado grupo, a Associação Brasileira de Relações Institucionais e Governamentais (Abrig), o qual conseguiu a modificação da nomenclatura de lobby para "agentes de relações governamentais", tendo referida 
instituição obtido também recente sucesso no reconhecimento da atividade de relações governamentais como ocupação pelo Ministério do Trabalho.

Apesar de bem-vinda a iniciativa de se estabelecerem regras para a atividade do lobista, certo é que a influência do poder econômico mais uma vez impedirá a edição de uma norma que realmente atenda ao interesse público. Isso porque, além das modificações ao projeto acima citadas, foi introduzido dispositivo que determina o credenciamento de profissionais da área. Isso, por si só, já restringe a atuação dos grupos de interesse com menor força política e econômica, criando-se um nicho de mercado restrito às pessoas previamente registradas, o que demonstra mais uma vez a grande influência do poder econômico em todas as esferas da vida pública.

Ao lado da figura do lobby, a captura é outra forma de influência na aprovação de normas legais. Ela surgiu na esfera das agências reguladoras e consiste na pressão exercida pelos setores regulados, detentores de poder econômico, para que a regulação exercida pela agência seja moldada para atender aos interesses dessas pessoas, em detrimento de uma efetiva regulação do mercado que atenda ao interesse público.

A despeito de sua origem, a figura da captura é perfeitamente adaptável ao âmbito legislativo, podendo os parlamentares ser cooptados pelo poder econômico para que atuem em seu benefício, assim como ocorre na captura de reguladores pelos regulados. Ressalte-se que nesse caso não há necessariamente corrupção envolvida, com pagamento de vantagens indevidas; há, sim, influência do poder econômico na edição das leis, pura e simples. Os detentores de influência econômica atuam perante o Poder Legislativo (ou o Executivo, nas hipóteses de sanção ou veto) em busca de vantagens.

Bagnoli (2009, p. 79) ressalta que "da mesma forma que os funcionários das agências podem ser capturados pelo poder privado, o político, para manter-se no poder (ou o seu partido), pode ser cooptado pelos interesses do poder econômico privado, ainda que em prejuízo da coletividade".

Quanto à terceira forma de influência do poder econômico na atuação legislativa, a corrupção, essa está embrenhada em nosso sistema jurídico. Recentemente foi constatada a possível ocorrência de pagamento de propina para aprovação de norma legal apta a favorecer determinado grupo de pessoas com influência econômica, caso esse que será exposto mais adiante.

Assim, a possibilidade de interferência da força econômica na função legislativa é real e ocorre diuturnamente, seja por meio de lobby, captura ou corrupção. No tópico seguinte analisaremos algumas ocorrências em que houve o abuso do poder econômico para influenciar a aprovação de normas que beneficiavam apenas uma minoria detentora de poder. 


\section{CASOS DE APROVAÇÃO DE NORMAS JURÍDICAS EM DESCOMPASSO COM O INTERESSE PÚBLICO POR INFLUÊNCIA DO PODER ECONÔMICO}

\subsection{Medida provisória 471/2009 - a "MP das Montadoras"}

Nas duas últimas décadas a União concedeu diversos incentivos fiscais ao setor automotivo. Um deles foi um benefício tributário instituído pela Lei 9.826/99, e que deveria viger somente até 31.12.2010. Usufruíam dessa benesse algumas montadoras, como a MMC Automotores do Brasil Ltda. e Caoa Montadora de Veículos S/A. Sobreveio então a medida provisória no 471 , de 20 de novembro de 2009, que prorrogou esse benefício².

Segundo a denúncia oferecida pelo Ministério Público Federal do Distrito Federal, normalmente a tramitação de uma medida provisória apresenta algumas circunstâncias usuais, havendo um percurso longo a ser seguido e que envolve agentes públicos e privados. No entanto, no caso da MP n ${ }^{\circ} 471 / 2009$, esse trajeto foi demasiadamente exíguo, o que ensejou a suspeita de existência de irregularidades. Nesse contexto, a Operação Zelotes, engendrada pela Polícia Federal em conjunto com a Receita Federal, apurou que houve a prática de corrupção na tramitação dessa norma, em suas duas fases.

A corrupção na segunda fase da edição da medida provisória (fase legislativa) foi confirmada por sentença condenatória lançada nos autos de processo $\mathrm{n}^{\circ}$ 0070091- 13.2015.4.01.3400, em fase de recurso perante o Tribunal Regional Federal da $1^{\text {a }}$ Região. Já a corrupção apurada na primeira fase da tramitação (fase da propositura) ainda não foi objeto de julgamento. No entanto, de acordo com a denúncia apresentada, as montadoras MMC e CAOA ofereceram dinheiro a agentes públicos, dentre eles o então presidente da República e seu chefe de gabinete, para que a medida provisória contendo incentivos fiscais que as beneficiavam fosse aprovada.

Dessa narrativa verifica-se o poder que determinados setores da economia tem na aprovação de leis. Claro que nesse caso a influência constitui-se inclusive em crime, mas certamente a corrupção somente foi possível em razão do poder que detém as empresas corruptoras. Seria bem difícil se imaginar a promessa de pagamento para induzir à aprovação de lei realizado por sociedade de pequena monta ou oriunda de área da economia sem relevância. Primeiro porque o interesse por ela defendido provavelmente seria de ínfima importância econômica, o que teria como consequência a oferta de um valor baixo a título de propina, que certamente não atrairia a atenção do corrompido. Ademais, uma empresa com pouca ou nenhuma influência econômica sequer teria acesso ao agente público responsável pelo ato objeto do delito. 


\subsection{Programa especial de regularização tributária (PERT)}

A medida provisória $\mathrm{n}^{\circ}$ 783, de 31 de maio de 2017, instituiu o Programa Especial de Regularização Tributária (PERT) com o objetivo de reduzir o litígio judicial tributário, além de proporcionar aos contribuintes condições especiais para negociar suas dívidas com a União. O prazo para adesão foi estendido pela medida provisória $n^{\circ} 798$, de 30 de agosto de 2017, que posteriormente foi convertida na Lei 13.496, de 24 de outubro de 2017.

De acordo com as regras do programa, a adesão deveria se dar até o dia 31 de outubro de 2017 e poderiam ser liquidados débitos perante a Secretaria da Receita Federal do Brasil e a Procuradoria-Geral da Fazenda Nacional (PGFN), de natureza tributária ou não tributária, inclusive que já tenham sido objeto de parcelamento anterior rescindido ou ativo, em discussão administrativa ou judicial. A opção pelo programa implica a confissão irrevogável e irretratável dos débitos indicados para compor o PERT.

O contribuinte ao aderir ao PERT tinha a possibilidade de optar por uma das seguintes modalidades no âmbito da Receita Federal do Brasil: (i) pagamento à vista e em espécie de, no mínimo, $20 \%$ do valor da dívida consolidada, sem redução, em 5 parcelas mensais e sucessivas vencíveis de agosto a dezembro de 2017, e a liquidação do restante com a utilização de créditos de prejuízo fiscal e base de cálculo negativa da Contribuição Social sobre o Lucro Líquido (CSLL) ou com outros créditos próprios relativos aos tributos administrados pela RFB; (ii) pagamento da dívida consolidada em até 120 prestações mensais e sucessivas; (iii) pagamento à vista e em espécie de, no mínimo, $20 \%$ do valor da dívida consolidada, sem redução, em 5 parcelas mensais e sucessivas, vencíveis de agosto a dezembro de 2017, e o restante: a) liquidado integralmente em janeiro de 2018, em parcela única, com redução de $90 \%$ dos juros de mora e $50 \%$ das multas de mora, de ofício ou isoladas; b) parcelado em até 145 parcelas mensais e sucessivas, vencíveis a partir de janeiro de 2018 , com redução de $80 \%$ dos juros de mora e de $40 \%$ das multas de mora, de ofício ou isoladas; ou c) parcelado em até 175 parcelas mensais e sucessivas, vencíveis a partir de janeiro de 2018, com redução de $50 \%$ dos juros de mora e de $25 \%$ das multas de mora, de ofício ou isoladas, sendo cada parcela calculada com base no valor correspondente a um por cento da receita bruta da pessoa jurídica, referente ao mês imediatamente anterior ao do pagamento, não podendo ser inferior a 1/175 (um cento e setenta e cinco avos) do total da dívida consolidada. Quem possui dívida total igual ou inferior a R\$ 15 milhões, ao optar pela terceira modalidade tem a benesse de redução do valor do pagamento à vista em espécie para, no mínimo, 7,5\% do valor da dívida consolidada, sem reduções, que deverá ser pago em 5 parcelas mensais e sucessivas, vencíveis de agosto a dezembro de 2017, bem como a possibilidade de utilização de créditos de prejuízo fiscal e de base de cálculo negativa da CSLL e de outros créditos próprios relativos aos tributos administrados pela RFB. 
Em relação aos débitos administrados pela Procuradoria-Geral da Fazenda Nacional, também há a previsão de parcelamento em 120 prestações mensais. As demais modalidades de pagamento à vista são similares àquelas de débitos geridos pela Secretaria da Receita Federal do Brasil, havendo alguma variação em relação a descontos e número de parcelas para liquidação do saldo restante, além de não ser possível o uso de créditos decorrentes de prejuízo fiscal.

Analisando-se as regras supra, verifica-se que umas das modalidades de liquidação do débito é o parcelamento propriamente dito, admitindo-se o pagamento do valor consolidado em certo número de prestações mensais e sucessivas. Nesse ponto não cabe nenhuma ponderação, ao contrário do que ocorre quanto às modalidades de pagamento à vista.

Com efeito, nas hipóteses de pagamento à vista, tanto perante a Procuradoria-Geral da Fazenda Nacional quanto a Secretaria da Receita Federal do Brasil, o legislador concedeu descontos enormes, havendo em alguns casos redução de $90 \%$ dos juros de mora e $70 \%$ das multas de mora, de ofício ou isoladas.

A redação original da medida provisória foi alterada durante sua tramitação no Poder Legislativo. Inicialmente os descontos não eram tão avantajados, mas mesmo assim a previsão de renúncia fiscal era de 6,06 bilhões nos três anos seguintes ao programa, sendo 2,91 bilhões somente em 2018. Após a aprovação, que se deu com base no parecer do deputado Newton Cardoso Júnior, segundo dados do Sindifisco Nacional a arrecadação passaria de 13,3 bilhões para apenas 420 milhões (BATISTA, 2017).

As condições são extremamente benéficas aos devedores. Mas as vantagens são igualmente boas para a Administração Pública? O interesse comum foi atingido com essa renúncia fiscal?

Os reiterados parcelamentos que vem sendo realizados todos os anos pela administração pública federal tem como justificativa a necessidade de incremento do caixa em curto espaço de tempo, bem como o incentivo à recuperação econômica das pessoas jurídicas, tendo em vista a crise financeira que assola o país já há alguns anos.

Em realidade, contudo, essa normatização benéfica aos contribuintes proporciona ao Estado federal muito mais desvantagens do que vantagens. Os parcelamentos reiterados são um estímulo ao inadimplemento e um desprestígio ao bom pagador. Isso porque os contribuintes deixam de recolher os tributos ao tempo e com o valor originalmente lançado porque sabem que seguramente, em um futuro próximo, haverá a edição de um novo benefício fiscal desse porte, prevendo inúmeras vantagens para aqueles que optarem por pagar seus débitos a destempo.

Ademais, apesar de haver ingresso repentino de valores nos cofres da União, a contrapartida a isso é a renúncia a um valor muito mais alto; por conta dessas benesses bilhões de reais deixam de adentrar o Tesouro Nacional, e isso 
para um Estado que se diz com sérias dificuldades financeiras. O mais grave é que todo esse capital poderia invariavelmente ser cobrado e revertido ao caixa federal integralmente.

A Procuradoria-Geral da Fazenda Nacional, responsável pela cobrança de créditos tributários ou não tributários inscritos em dívida ativa da União, poderia fazer seu papel com maior eficiência se houvesse interesse político para tanto: o investimento na instituição, com a melhoria de sistemas, treinamento apropriado e contratação de servidores para fazer atividades administrativas ${ }^{6}$ já seriam uma ótima iniciativa para aprimorar a cobrança dos créditos da administração pública federal.

Essas pequenas mudanças trariam incontáveis vantagens para a União, que não precisaria renunciar a valores por meio de dispositivos claramente mais benéficos aos devedores que a ela. No entanto, essa alteração de postura interessa a quem? Certamente não ao poder econômico.

$\mathrm{E}$ as incongruências vão além.

Em relação ao Programa Especial de Regularização Tributária, cabe registrar que muitas das dívidas nele incluídas, e cujo pagamento foi permitido com descontos vultosos, referem-se a débitos previdenciários previstos no art. 195, I, da Constituição Federal, que se destinam ao financiamento da Seguridade Social.

Ora, diante do discurso nacional e propaganda institucional amplamente promovida pela Administração Pública Federal no sentido de que há um grande déficit na previdência social, a qual deverá ser reformada com grave prejuízo aos segurados e pensionistas sob o argumento de desequilíbrio entre receitas e despesas, no mínimo gera estranheza a concessão de redução de até $90 \%$ dos juros de mora e $70 \%$ das multas de mora, de ofício ou isoladas em relação aos débitos que justamente financiam o caixa dessa previdência social. Se há necessidade de cortes de benefícios para manutenção de um mínimo de pagamentos em razão da ausência de receita suficiente, carece de qualquer lógica a concessão de descontos nas contribuições que compõem essa mesma receita defasada.

Nesse ponto é que se vislumbra mais uma vez a influência do poder econômico. Muitos dos contribuintes beneficiados são grandes devedores da União, que fizeram uso de sua posição no mercado para cooptar os legisladores e induzi-los a promover as alterações que lhes eram benéficas. Tanto que a redação original da medida provisória não previa tantos abatimentos, porém, quando passou a tramitar no Congresso Nacional, foi modificada para acréscimo de descontos muito mais vantajosos aos contribuintes inadimplentes.

Novamente deve se ressaltar que as pessoas influenciadoras na hipótese somente podem ser detentoras de poder econômico (ou poder político, como se verá adiante), sendo difícil se imaginar que pequenos empresários teriam 
capacidade para influir na tomada de decisão dos membros do Legislativo, ainda mais em situação que envolve a renúncia fiscal de bilhões de reais.

A força do poder econômico foi sentida também na própria proposta de reforma da previdência, especialmente a dos servidores públicos. Não há dúvidas de que as instituições financeiras realizaram grande pressão para sua iniciativa, na medida em que pretendem abocanhar a fatia de mercado que surgirá com a migração dos servidores para planos de previdência complementar.

Quanto à influência política, que normalmente guarda estreita relação com o poder econômico, na aprovação do Programa Especial de Regularização Tributária ela foi percebida de forma muito clara.

Segundodadosinformados pela Procuradoria-Geralda Fazenda Nacional ${ }^{7}$, há setenta deputados federais com dívidas próprias contra a União, perfazendo o montante de $\mathrm{R} \$ 23.865 .130,76$ em maio de 2017, e vinte corresponsabilizados por débitos de terceiros, incluindo pessoas físicas e jurídicas, totalizando R \$ 168.848.829,19. Há também 109 deputados ligados a empresas devedoras da União, com um total de $\mathrm{R} \$ 363.985 .377,43$ em dívidas. Dentre esses deputados está listado Newton Cardoso Júnior, que emitiu parecer na MP 783/2017, e deve $\mathrm{R} \$ 141.596,20$ a título próprio e está vinculado a pessoas jurídicas com débitos de $\mathrm{R} \$ 53.422 .178,43$ inscritos na dívida ativa da União.

Além dos deputados, há dezoito senadores com dívidas próprias somadas de $\mathrm{R} \$ 7.299 .948,16$ e cinco corresponsáveis por dívidas de terceiros no importe de $\mathrm{R} \$ 72.780 .065,27$. Há ainda 22 senadores vinculados a pessoas jurídicas com dívidas inscritas no valor total de $\mathrm{R} \$ 241.287 .937,27$.

Como se não bastasse, nessa lista elaborada pela Procuradoria-Geral da Fazenda Nacional há um grande número de empresas devedoras da União que financiaram campanhas eleitorais para o cargo de deputado federal e que possuem débitos somados de $\mathrm{R} \$ 206.466 .014 .165,49$; as pessoas jurídicas que financiaram campanhas eleitorais para o cargo de senador devem $\mathrm{R} \$ 39.199 .123 .779,05$, o que demonstra mais uma vez a grande influência exercida pelo poder econômico na aprovação de normas voltadas para seus próprios interesses.

Mais uma vez restou muito claro: o interesse público é invariavelmente abandonado quando há um poder econômico interessado na defesa de seus próprios interesses privados. $\mathrm{E}$ isso com o aval de nossos governantes $\mathrm{e}$ representantes legislativos, em claro prejuízo ao bem comum.

\section{CONCLUSÃO}

O discurso que frequentemente é realizado no sentido de que o poder econômico não deveria existir, sendo ele o causador de todos os malefícios, é um discurso vazio e não corresponde à realidade. O poder econômico é essencial à 
manutenção do Estado e à existência da sociedade. Sem o poder econômico não haveria progresso e permaneceríamos estagnados.

Diante dessa constatação, não se pode pretender acabar com o poder econômico. No entanto, ele deve ser balizado e submetido a certo controle, justamente para evitar abusos.

Inicialmente devemos garantir que a soberania popular seja respeitada e efetivamente exercida. Os instrumentos de exercício direto do poder político devem ser efetivos, não se colocando empecilhos à iniciativa popular, plebiscito e referendo. Do mesmo modo, a forma indireta de exercício desse poder, que se dá por meio do voto, deve ser assegurada plenamente.

Se isso não for feito, a exemplo dos vários eventos que ocorrem diuturnamente no Brasil, não mais se poderá falar em juspositivismo. À medida que o devido processo legislativo não é respeitado, havendo a edição de leis para atender a interesses próprios ou de terceiros, à revelia do interesse público, contrariando-se a Constituição, concluímos que o positivismo de Kelsen não está sendo aplicado. Na verdade, o que temos na prática é o não juspositivismo, sobrepujando o poder a norma emanada do Estado; a teoria de Carl Schmitt se fazendo presente, sendo o direito maior que o ordenamento jurídico.

A fim de se contornar essa situação, impedindo-se a prevalência do poder em detrimento do interesse de toda uma nação, o primeiro passo é a moralização pública, tornando-se efetivas a coibição e punição de delitos por parte dos representantes do povo. Mas isso não basta: a população também deve agir, seja exigindo que os políticos cumpram suas promessas eleitorais, seja fiscalizando a atuação desses representantes e, mais importante, deixando de reeleger aqueles que não se mostraram aptos a ocupar o cargo de representante dos interesses do povo.

Somente se tomando essas posturas iniciais o abuso por parte do poder econômico e sua influência ilícita na edição de normas jurídicas já seriam amplamente combatidos. Casos de corrupção como aquele constatado na tramitação da "MP das Montadoras" poderiam ser evitados, assim como a atuação em causa própria perpetrada pelos membros da Câmara dos Deputados e do Senado Federal quando da aprovação das reduções de multa e juros previstas no Programa Especial de Regularização Tributária veiculado pela Lei 13.496/2017.

Em um segundo momento, o Estado deve adotar postura ativa na regulamentação das atividades do poder econômico, especialmente no que tange à influência desse último para aprovação de normas que lhe gerem benefícios particulares. A captura e o lobby devem ser regulados, mas não impedidos. Afinal, essas duas figuras fazem parte da democracia, o mesmo não se podendo dizer da corrupção.

Por fim, tomadas todas as providências anteriores, em tese os abusos do poder econômico serão contidos. A pressão para a edição de normas em seu favor continuará a existir, o que é natural, mas será realizada de maneira menos incisiva, 
permitindo-se também a influência de grupos com menos poder. De igual modo, teremos de novo a regência do juspositivismo, restringindo-se o direito às normas emanadas do Estado; o poder deixará de governar o direito, limitando-se ele ao ordenamento jurídico puro e simples.

Mas isso tudo no mundo ideal. Porque é sabido que mudanças dessa proporção não são fáceis de serem implementadas e, até que o sejam, haverá muitos casos de sobreposição de interesses particulares em detrimento do interesse da coletividade. E os representantes do povo continuarão a fazer uso do Estado em proveito próprio.

\section{NOTAS}

1 Essa constatação já leva a crer que o juspositivismo não é a única forma de pensamento contemporâneo atualmente existente no Brasil. O não juspositivismo - o direito é o que o detentor de poder diz, e não o que está nas estritas normas jurídicas - tem larga presença em nosso ordenamento jurídico, mesmo que não se admita formalmente.

2 As informações criminas referente aos benefícios dessas duas empresas podem ser detalhadas na ação penal 0037544-46.2017.4.01.3400, em trâmite perante Juízo da 10a Vara Federal Criminal do Distrito Federal.

\section{REFERÊNCIAS}

BAGNOLI, Vicente. Direito e poder econômico: os limites jurídicos do imperialismo frente aos limites econômicos da soberania. Rio de Janeiro: Elsevier, 2009.

BATISTA, Vera. Sindifisco critica MP 783. Correio Braziliense: Blog do Servidor. Brasília, p. 1-1. 18 jul. 2017. Disponível em: <http://blogs.correiobraziliense.com.br/ servidor/sindifisco-critica-mp-783/>. Acesso em: 26 nov. 2018.

BRASIL. Constituição da República Federativa do Brasil de 1988. Disponível em: <http://www.planalto.gov.br/ccivil_03/Constituicao/ConstituicaoCompilado.htm >. Acesso em: 02 nov. 2018.

BRASIL. Lei 9.709, de 18 de novembro de 1998. Disponível em: <http://www.planalto. gov.br/ccivil_03/Leis/L9709.htm>. Acesso em: 26 nov. 2018.

BRASIL. Lei 9.826, de 23 de agosto de 1999. Disponível em: <https://www.planalto. gov.br/ccivil_03/LEIS/L9826.htm>. Acesso em: 26 nov. 2018.

BRASIL. Lei 12.218, de 30 de março de 2010. Disponível em: <http://www.planalto. gov.br/ccivil_03/_Ato2007-2010/2010/Lei/L12218.htm>. Acesso em: 26 nov. 2018.

BRASIL. Lei 13.496, de 24 de outubro de 2017. Disponível em: <http://www.planalto. gov.br/ccivil_03/_ato2015-2018/2017/lei/L13496.htm>. Acesso em: 26 nov. 2018. 
BRASIL. Medida Provisória n. 471, de 20 de novembro de 2009. Disponível em: <http://www.planalto.gov.br/ccivil_03/_Ato2007-2010/2009/Mpv/471.htm>. Acesso em: 26 nov. 2018.

BRASIL. Medida Provisória n. 783, de 31 de maio de 2017. Disponível em: <http:// www.planalto.gov.br/ccivil_03/_ato2015-2018/2017/Mpv/mpv783.htm>. Acesso em: 26 nov. 2018.

BRASIL. Medida Provisória n. 798, de 30 de agosto de 2017. Disponível em: <http:// www.planalto.gov.br/ccivil_03/_Ato2015-2018/2017/Mpv/mpv798.htm>. Acesso em: 26 nov. 2018.

BRASIL. PROCURADORIA-GERAL DA FAZENDA NACIONAL. Nota de esclarecimento PGFN/CGR n. 001, de 01 de maio de 2017. Disponível em https:// kikacastro.files.wordpress.com/2017/05/parlamentares_devedores_fisco.pdf. Acesso em: 26 nov. 2018.

BRASIL. PROCURADORIA-GERAL DA FAZENDA NACIONAL. Qual a forma de liquidação. 2018. Disponível em: <http://www.pgfn.fazenda.gov.br/servicos-eorientacoes/servicos-da-divida-ativa-da-uniao-dau/parcelamentos-1/copy_of_ parcelamentos/programa-especial-de-regularizacao-tributaria-2013-pert-2013-mp- 7832017/qual-a-forma-de-liquidacao/>. Acesso em: 26 nov. 2018.

BRASIL. Projeto de Lei 1.202, de 2007. Disponível em: <http://www.camara.gov.br/ proposicoesWeb/prop_mostrarintegra;jsessionid=675FC7C62D33CA1F43B280026502 4D66.proposicoesWebExterno2? codteor $=465814 \&$ filename $=P L+1202 / 2007$. Acesso em: 26 nov. 2018.

BRASIL. RECEITA FEDERAL DO BRASIL. Programa Especial de Regularização Tributária (PERT). 2017. Disponível em: <https://idg.receita.fazenda.gov.br/noticias/ ascom/2017/programa-especial-de-regularizacao- tributaria-pert $>$. Acesso em: 26 nov. 2018

FERRAZ JUNIOR, Tércio Sampaio. SALOMÃO FILHO, Calixto. NUSDEO, Fabio. Poder econômico: direito, pobreza, violência, corrupção. Organ. Barueri: Manole, 2009.

MASCARO, Alysson Leandro. Introdução ao estudo do direito. 5.ed. São Paulo, Atlas, 2015.

Submetido: 2019-08-26

Aceito: 2019-10-30 


\title{
A INFLUÊNCIA DO PODER ECONÔMICO NA APROVAÇÃO DE NORMAS JURÍDICAS E SUA RELAÇÃO COM AS TEORIAS SOBRE O PENSAMENTO JURÍDICO CONTEMPORÂNEO
}

\begin{abstract}
Resumo
Nesse artigo propõe-se uma análise da influência do poder econômico na aprovação de normas jurídicas, especialmente no que tange a benefícios fiscais, como ocorreu com a medida provisória n. 471, de 20 de novembro de 2009, conhecida como "MP das Montadoras", e o Programa Especial de Regularização Tributária - PERT, instituído pela medida provisória 783 , de 31 de maio de 2017, cujo prazo para adesão foi prorrogado pela medida provisória n. 798 , de 30 de agosto de 2017, posteriormente convertida na Lei 13.496, de 24 de outubro de 2017, fazendo-se um paralelo com as teorias sobre o pensamento jurídico contemporâneo. Inicialmente abordaram-se questões envolvendo a soberania popular e seu modo de exercício, abordando aspectos concernentes ao plebiscito, referendo, iniciativa popular e representação exercida por meio do voto. Em seguida foram tecidos breves comentários sobre a relação público/privado e a dependência e mútuo apoio entre esses dois aspectos opostos. Foram então analisadas as teorias que compõem o pensamento jurídico contemporâneo - juspositivismo, não juspostivismo e pensamento crítico e, após, as formas de influência do interesse privado na atividade legislativa, especialmente a pressão exercida pelo poder econômico nessa seara e, por fim, o modo como esse poder atuou para satisfação de seus interesses no âmbito da MP 471/2009 ("MP das Montadoras") e no Programa de Especial de Regularização Tributária - PERT.
\end{abstract}

Palavras-chave: Poder econômico. Aprovação normas jurídicas. Benefícios fiscais. 


\title{
THE INFLUENCE OF ECONOMIC POWER ON THE APPROVAL OF LEGAL NORMS AND THEIR RELATIONSHIP WITH THEORIES ON CONTEMPORARY LEGAL THOUGHT
}

\begin{abstract}
This article proposes an analysis of the influence of the economic power in the approval of legal norms, especially with regard to tax benefits, as occurred with the provisional measure n. 471, of November 20, 2009, known as the "MP of Assemblers," and the Special Program for Tax Regularization - PERT, instituted by Provisional Measure 783, of May 31, 2017, whose term for adhesion was extended by Provisional Measure 798, of August 30, 2017 , later converted into Law No. 13,496, of October 24, 2017, drawing a parallel with the theories on contemporary legal thinking. Initially, issues involving popular sovereignty and the manner in which it is exercised were addressed, addressing aspects related to the plebiscite, referendum, popular initiative and representation exercised through voting. This was followed by brief comments on the public/private relationship and the dependence and mutual support between these two opposing aspects. We then analyzed the theories that make up contemporary legal thinking - juspositivism, nonjuspostivism and critical thinking - and then the forms of influence of private interest on legislative activity, especially the pressure exerted by economic power in this area and, finally, the way this power acted to satisfy its interests under Provisional Measure 471/2009 ("MP of Assemblers") and the Special Program for Tax Regularization - PERT.
\end{abstract}

Keywords: Economic power. Approval of legal rules. Tax benefits 